\title{
PEMBERDAYAAN GURU PENDIDIKAN AGAMA ISLAM MELALUI PENINGKATAN KOMPETENSI GURU PADA TINGKAT SEKOLAH DASAR DI WAIMITAL
}

\author{
St. Jumaeda, La Rajab, Nur Khozin \\ Program Studi PAI FITK IAIN Ambon \\ Edha amel77@yahoo.com
}

\begin{abstract}
Abstrak: Pemberdayaan peningkatan kompetensi guru Pendidikan Agama Islam pada tingkat Sekolah Dasar di Waimital Kabupaten Seram Bagian Barat bertujuan untuk menambah wawasan dan pengetahuan guru Pendidikan Agama Islam pada tingkat sekolah dasar di kabupaten Seram Bagian Barat khususnya dalam bidang pembuatan soal dan penulisan Al-Qur'an. Pemberdayaan ini terdiri atas tiga tahapan yaitu, penyadaran tentang pentingya penilaian dalam kegiatan pembelajaran, peningkatan pemahaman tentang pembuatan soal ujian dan penulisan Al-Qur'an ,dan implementasi dalam kegiatan pembelajaran. pemberdayaan guru PAI menggunakan modifikasdi action research. Langkah operasionalnya meliputi: perencanaan, pelaksanaan, pengamatan, dan refleksi/evaluasi. Hasil analisis data menunjukkan bahwa terdapat peningkatan kesadaran guru PAI pada tingkat sekolah Dasar berpartisipasi dalam kegiatan pembelajaran pelatihan penulisan soal dan penulisan Al-Qur'an yang terbukti antusiaasnya para guru untuk belajar dalam kegiatan ini, sehingga dapat dapat mengaplikasikan ilmu yang didapatkan dalam kegiatan pembelajaran di sekolah.
\end{abstract}

Kata Kunci: Pemberdayaan Guru PAI, Sekolah Dasar

\section{PENDAHULUAN}

Pemberdayaan ( empowering) dalam pendidikan luar sekolah di Indonesia pertama kali dikembangkan oleh Kindervatter (1979:13). Menurutnya pemberdayaan merupakan suatu proses pemberian kekuatan atau daya dalam bentuk pendidikan yang bertujuan membangkitkan kesadaran, pengertian, dan kepekaan warga belajar terhadap perkembangan social, ekonomi dan politik, sehingga memiliki kemampuan untuk memperbaiki dan meningkatkan kedudukan dalam masyarakat.

Secara historis, konsep pemberdayaan telah mengalami perkembangan. Menurut Kieffer bahwa ide pemberdayaan mulai dikenal 
pada tahu 1960-an ketika terjadi suatu aksi (social action). Aksi social ini dikembangkan oleh Berger dan Neuhaus sekitar tahun 1970-an dan terus berubah menjadi suatu geraka self help. Istilah pemberdayaan telah berkembang secara meluas dan mulai popular sekitar tahun 1980-an sebagai suatu strategi prevensi dan intervensimasyarakat yang telah dikembangkan oleh Englebrg, Rappaport, dan Hess. Menurutnya bahwa pemberdayaan yang semula hanya dikenal pada tingkat mikro-individual, telah bergeser dan berkembang ke arah pemberdayaan kelompok dan masyarakat. Pemberdayan kini digunakan sebagai suatu aksi, gerakan dan strategi dalam mengatasi masalah-masalah individual dan kelompok (Saraka, 2002: 134). Kegiatan pemberdayaan guru PAl pada tingkat sekolah dasar di Waimital bertujuan untuk mengembangkan potensi yang dimiliknyai secara maksimal, dengan pembelajaran yang mengarah pada peningkatan motivasi, kreatifitas, imajinasi dan inovasi dan etos keilmuan ( Nata, 2003:4). Guru sangat memerlukan aneka ragam pengetahuan dan keterampilan yang memadai dalam arti sesuai dengan tuntutan zaman dan kemajuan sains dan teknologi (Syah, 2002:1). Dinamisasi dalam banyak hal pada proses pembelajaran tersebut yang pada akhirnya tujuan pendidikan dalam skala micro maupun makro akan terwujud. Sehingga siswa mempunyai bekal ilmu pengetahuan dan kompetensi yang cukup pada masanya, dan tumbuh motivasi untuk selalu mengembangkannya di masa yang akan datang. 
Kompetensi guru terkait dengan kewenangan melaksanakan tugasnya, dalam hal ini dalam menggunakan bidang studi sebagai bahan pembelajaran yang berperan sebagai alat pendidikan, dan kompetensi pedagogis yang berkaitan dengan fungsi guru dalam memperhatikan perilaku peserta didik belajar (Djohar,2006:130). Kompetensi guru merupakan hasil dari penggabungan kemampuankemampuan yang banyak jenisnya, dapat berupa seperangkat pengetahuan, keterampilan, dan perilaku yang harus dimiliki, dihayati, dan dikuasai oleh guru dalam menjalankan tugas keprofesionalannya. Menurut Suparlan (2008:93) bahwa standar kompetensi guru dipilah ke dalam tiga komponen yang saling berkaitan, yaitu pengelolaan pembelajaran, pengembangan profesi, dan penguasaan akademik. Menurut Peraturan Menteri Pendidikan Nasional Republik Indonesia Nomor 16 Tahun 2007 Tentang Standar Kualifikasi Akademik dan Kompetensi Guru, adapun macam-macam kompetensi yang harus dimiliki oleh tenaga guru antara lain: kompetensi pedagogik, kepribadian, profesional dan sosial yang diperoleh melalui pendidikan profesi. Keempat kompetensi tersebut di atas bersifat holistik dan integratif dalam kinerja guru. Oleh karena itu, secara utuh sosok kompetensi guru meliputi (a) pengenalan peserta didik secara mendalam; (b) penguasaan bidang studi baik disiplin ilmu (disciplinary content) maupun bahan ajar dalam kurikulum sekolah (c) penyelenggaraan pembelajaran yang mendidik yang meliputi perencanaan dan pelaksanaan pembelajaran, evaluasi proses 
dan hasil belajar, serta tindak lanjut untuk perbaikan dan pengayaan; dan (d) pengembangan kepribadian dan profesionalitas secara berkelanjutan. Guru yang memiliki kompetensi akan dapat melaksanakan tugasnya secara profesional (Ngainun Naim, 2009:60).

Guru merupakan salah satu faktor yang sangat penting dalam meningkatkan kualitas pendidikan, khususnya Guru Pendidikan Agama Islam, karena disamping mempunyai peran mentransfer ilmu, guru PAI juga mempunyai peran dalam membantu proses internalisasi moral kepada siswa. Selain itu juga harus mempunyai bekal berupa persiapan diri untuk menguasai sejumlah pengetahuan, ketrampilan, dan kemampuan khusus sebagai kompetensi dasar yang terkait dengan profesi keguruannya agar ia dapat menjalankan tugasnya dengan baik serta dapat memenuhi kebutuhan dan harapan peserta didiknya. Jadi, guru PAI diharapkan mampu membawa peserta didiknya menjadi manusia yang "sempurna" baik lahiriah maupun batiniah (Yusuf:2006, 364).

Secara faktual, pelaksanaan internalisasi nilai dan transformasi pengetahuan pada peserta didik merupakan tugas yang cukup berat di tengah kehidupan masyarakat yang kompleks apalagi pada era globalisasi dan modernisasi ini. Untuk mengaktualisasikan pelaksanaan tersebut dalam pendidikan agama Islam, pendidik atau gurulah yang mempunyai tanggung jawab mengantarkan manusia ke arah tujuan tersebut. Dengan ini, keberadaan pendidik dalam dunia pendidikan sangatlah krusial, sebab kewajibannya tidak hanya mentransformasikan pengetahuan (knowledge), 
tetapi juga dituntut menginternalisasikan nilai-nilai (value) pada peserta didik. Bentuk nilai yang diinternalisasikan paling tidak meliputi: nilai etika (akhlak), estetika sosial, ekomis, politik, pengetahuan, pragmatis, dan nilai ilahiyyah (Ramayulis: 2009,8).

Untuk menjadi pendidik profesional tidaklah mudah, karena ia harus memiliki berbagai kompetensi-kompetensi keguruan. Kompetensi dasar (basic competency) bagi pendidik ditentukan oleh tingkat kepekaannya dari bobot potensi dasar dan kecenderungan yang dimilikinya. Hal tersebut karena kompetensi itu merupakan tempat dan bahan untuk memproses semua pandangan sebagai bahan untuk menjawab semua rangsangan yang datang darinya. Dengan demikian, seorang pendidik harus mempunyai persiapan diri untuk menguasai sejumlah pengetahuan, keterampilan, dan kemampuan khusus yang terkait dengan profesi keguruannya, agar ia dapat menjalankan tugasnya dengan baik, serta dapat memenuhi keinginan dan harapan peserta didiknya.

Berdasarkan dari penelitian pendahuluan bahwa jumlah guru Pendidikan Agama Islam pada tingkat Sekolah Dasar di Kabupaten Seram Bagian Barat berjumlah 125 guru. Permasalahan utama dalam pembelajaran Pendidikan Agama Islam adalah penggunaan metode pembelajaran dalam menyampaikan materi pelajaran kurang tepat, dalam memenuhi muatan tatanan nilai, yang dapat diinternalisasikan pada diri siswa serta mengimplementasikan hakikat pendidikan nilai 
dalam kehidupan sehari-hari belum memenuhi harapan seperti yang diinginkan.

\section{METODE}

Kegiatan ini sebagai pemberdayaan masyarakat sekolah yang menggunakan modifikasi action research. Langkah operasionalnya meliputi: perencanaan, pelaksanaan, pengamatan, dan refleksi/evaluasi. Kronologis kegiatan tersebut dilakukan secara bersiklus dan bedasarkan perkembangan subjek dampingan, sehingga berlangsung dalam tiga tahap.

\section{HASIL}

\section{Perencanaan}

Perencanaan kegiatan Pemberdayaan pembelajaran dan peningkatan kompetensi guru, relevan dengan kondisi dan kebutuhan guru PAI pada tingkat sekolah dasar di Waimital dilakukan baik secara individu maupun secara simultan (beberapa orang), melaui forum pertemuan formal maupun informal. Jenis pelatihan yang akan dijadikan instrument aksi, adalah pelatihan membuat soal ujian dan pelatihan penulisan ayat AI-Qur'an dengan baik dan benar.

\section{Pelaksanaan}

Peserta pelatihan terdiri atas usia 35-48 tahun, tingkat pendidikan tinggi S1 (strata satu). Pelaksanaan pelatihan dilakukan dalam dua bagian yaitu 1) pelatihan membuat soal, 2) pelatihan menulis ayat AlQur'an dengan baik dan benar. Pelatihan membuat soal membahas materi tentang pengembangan Soal HOTS, taksonomi Bloom yang 
meliputi kognitif, afektif dan psikomotorik, karakteristik soal HOTS bagaimana tata cara membuat soal disesuaikan dengan kemampuan dan karakteristik peserta didik. Di samping itu dicontohkanlah tata cara membuat soal berdasarkan dari indikator dan kemudian disesuaikan dengan kemampuan dan karakteristik peserta didik. Kemudian dijelaskan pula hal-hal yang mengenai soal yang baik dan dan bagaimana membuat kisi-kisi soal sebelum membuat soal. Selanjutnya untuk materi penulisan al-qur,an dimulai dengan penjelasan tentang bagaimana penulisan dengan menggunakan khat Nashki sebagai khat dasar, sehingga pengetahuan tetang penulisan khat Naskhi dapat dikuasai dengan berbagai metode penulisan yang baik dan benar, yang diikuti oleh ukuranukuran yang telah dirumuskan secara telaten dan detail. Praktek pembelajaran pengembangan membuat soal bertujuan untuk meningkatkan pemahaman guru SD tentang konsep penyusunan soal serta meningkatkan keterampilan guru SD untuk menyusun butir soal.

Pelaksanaan pelatihan menulis ayat-ayat al-Qur'an diawali dengan penjelasan secara singkat tentang bagaimana tatacara menulis al-Qur'an dengan baik dan benar, penulisan dengan menggunakan khat naskhi sebagailkhat dasar, dan tatacara menulis huruf sambung dalam rangka mengsah keterampilan dasar menulis ayat-ayat al-qur'an secara praktis, sehingga dapat mengenal dan memperdalam seni kaligrafi (khat indah Bahasa Arab) dengan mudah, baik dengan cara belajar sendiri maupun melalui bimbingan tutor. Karena untuk menguasai penulisan khat dengan 
indah membutuhkan waktu tidak sebentar, namun para guru Pendidikan Agama Islam dituntut untuk serius dan tekun dalam mempelajarinya agar tujuan yang diinginkan dapat tercapai. Kegiatan pelatihan berlangsung secara informal dengan menggunakan metode demonstrasi, dimana warga belajar pelatihan dilibatkan langsung dalam kegiatan demonstrasi, dan tutor hanya memfasilitasi kegiatan belajar mereka.

\section{Evaluasi dan Refleksi}

Bedasarkan dari kegiatan pelatihan yang dilakukan, dapat disipulkan bahwa secara menyeluruh dari semua subyek terjadi peningkatan, dalam arti bahwa terjadi perubahan pengetahuan dan sikap subyek terhadap pelaksanaan tindakan ini. Meskipun demikian masih terdapat beberapa saran perbaikan dari warga belajar berdasarkan hasil dialog antara fasilitator dengan warga belajar, seperti perlunya adanya modul pembelajaran, Berdasarkan hasil wawancara dan pengamatan sehingga dipandang perlu adanya perubahan dalam rangka perencanaan untuk tahap selanjutnya.

\section{PEMBAHASAN}

Kegiatan pelatihan dilakukan dengan cara sederhana dan dilaksanakan secara informal dengan harapan kegiatan ini akan berjalan secara kekeluargaan yang penuh dengan keakraban dan tanpa ada jarak yang jauh antara tutor dengan warga belajar. 
Pelatihan bagian pertama tentang pembuatan soal, dimulai dengan penjelasan tentang pengembangan soal HOTS, para warga belajar mendengarkan penjelasan tutor dengan seksama, sesekali terjadi diskusi kecil diantara mereka bahkan ada beberapa pertanyaan yang diajukan kepada tutor, menurut mereka tata cara yang diajarkan oleh tutor berbeda dengan tata cara yang mereka lakukan dalam pembuatan soal ketika akan melakukan evaluasi terhadap peserta didiknya, mereka menyadari bahwa apa yang dilakukan selama ini tidaklah tepat, karena itu mereka aka membuat soal ujian sesuai dengan syarat-syarat membuat soal yang baik dan benar berdasarkan dari indikator dan karakteristik serta kemampuan peserta didik. Kegiatan pelatihan bagian kedua tentang penulisan alQur'an dengan baik dan benar, dilakukan secara informal dengan harapan agar kegiatan pelatihan ini berjalan secara kekeluargaan, penuh dengan keakraban tanpa ada jarak pemisah antara tutor dan warga belajar. Tutor memberikan penjelasan sekilas tentang khat naskhi sebagai khat dasar dalam penulisan Bahasa Arab, warga belajar dengan seksama mendengarkan penjelasan dari tutor, dilanjutkan dengan menjelaskan tata cara penulisan yang baik dan benar, letak huruf, tebal tipisnyan huruf dan teknik penulisan bahasa Arab yang benar.

Aktifitas warga belajar yang diamati saat pelaksanaan kegiatan pelatihan, memperhatikan apa yang disampaikan oleh tutor, namun diantara mereka terlibat bisik-bisik saat dijelaskan materi, maka pada saat yang sama tutor memancing dengan bertanya apakah materi yang kami 
sampaikan berbeda dengan tata cara yang ibu lakukan selama ini? salah seorang warga belajar mengakui bahwa materi yang disampaikan oleh tutor berbeda dengan kebiasaan yang mereka lakukan dalam kegiatan pembelajaran di kelas, mereka menyadari bahwa apa yang dilakukan selama ini tidaklah tepat, karena itu mereka aka membuat soal ujian sesuai dengan syarat-syarat membuat soal yang baik dan benar berdasarkan dari indikator dan karakteristik serta kemampuan peserta didik. Demikian pula untuk pelatihan menulis al-qur'an. Tutor selanjutnya menjelaskan bahwa apa yang telah dilakukan tidak salah, namun yang lebih tepat dan sesuai adalah yang telah didemonstrasikan dalam pelatihan ini.

\section{KESIMPULAN}

Secara umum, penelitian aksi ini telah mencapai tujuan yakni memberikan pelatihan dan mengembangkan pengetahuan tentang pembuatan soal ujian dan teknik penulisan ayat al-Qur'an dengan baik dan benar kepada Bapak/Ibu guru pendidikan Agama Islam di Waimital Kecamatan Kairatu Kabupaten Seram Bagian Baratdalam rangka peningkatan kompetensi guru PAI pada tingkat sekolah Dasar. Pelatihan peningkatan kompetensi guru PAI ini dilakukan berdasarkan pertimbangan bahwa pada dasarnya guru PAI pada tingkat sekolah Dasar memilki potensi untuk maju dan berkembang sepanjang ada peluang yang diberikan diantaranya melalui pemberdayaan potensi mereka dengan memanfaatkan kemampuan dan motivasi mereka untuk meningkatkan 
kompetensinya serta mengembankan pengetahuan mereka tentang ilmuilmu kependidikan.

\section{DAFTAR PUSTAKA}

[1] Ali, Muhammad Guru Dalam Proses Belajar Mengajar, Bandung: Sinar Baru Algesindo, 1996.

[2] Fuad Yusuf, Choirul dkk, Inovasi Pendidikan Agama dan Keagamaan, Departemen Agama RI: 2006.

[3] Kindervatter, S. (). Nonformal Education as an Empowering Process. Massachusetts: Center for Internasional Education University Of Massachusetts. 1979

[4] Nadler, L. Designen Training Programs; The Critical Events Model. London: Addison Wesley Publishing Company 1982.

[5] Nata, Abudin IImuPendidikan Islam, Jakarta: Kencana Prenada Media Group, 2010.

[6] Ramayulis, Hakikat Peerta Didik dalam Pendidikan Islam, Salatiga: STAIN Batusangkar, 2007.

[7] Syah, Muhibin Psikologi Pendidikan dengan Pendekatan Guru, Bandung: Remaja Rosdakarya, 2000.

[8] Saraka, Model Pembelajaran Swaraah dalam pengembangan sikap Mental Wiraswasta, Disertasi Doktor pada PPS UPI Bandung, Tidak diterbitkan. 